\title{
Regional modeling of climate change impacts on smallholder agriculture and ecosystems in Central America
}

\author{
Lee Hannah $^{1}$ - Camila I. Donatti ${ }^{1}$ Celia A. Harvey ${ }^{1}$. \\ Eric Alfaro ${ }^{2}$ - Daniel Andres Rodriguez ${ }^{3}$. \\ Claudia Bouroncle ${ }^{4}$ - Edwin Castellanos ${ }^{5}$. \\ Freddy Diaz ${ }^{5}$ - Emily Fung ${ }^{4} \cdot$ Hugo G. Hidalgo ${ }^{2}$. \\ Pablo Imbach ${ }^{4}$ • Peter Läderach ${ }^{6}$ • Jason P. Landrum ${ }^{7}$. \\ Ana Lucía Solano 5
}

Received: 16 November 2015 / Accepted: 2 December 2016 /Published online: 27 December 2016

(C) The Author(s) 2016. This article is published with open access at Springerlink.com

\begin{abstract}
Climate change will have serious repercussions for agriculture, ecosystems, and farmer livelihoods in Central America. Smallholder farmers are particularly vulnerable due to their reliance on agriculture and ecosystem services for their livelihoods. There is an urgent need to develop national and local adaptation responses to reduce these impacts, yet evidence from historical climate change is fragmentary. Modeling efforts help bridge this gap. Here, we review the past decade of research on agricultural and ecological climate change impact
\end{abstract}

This article is part of the Special Issue "Climate change impacts on ecosystems, agriculture and smallholder farmers in Central America” edited by Camila I. Donatti and Lee Hannah.

Lee Hannah

lhannah@conservation.org

1 Betty and Gordon Moore Center for Science, Conservation International, Arlington, VA, USA

2 Center for Geophysical Research and School of Physics, University of Costa Rica, San Pedro, Costa Rica

3 Earth System Science Center, National Institute for Space Research of Brazil, São Paulo, Brazil

4 Tropical Agricultural Research and Higher Education Center (CATIE), Turrialba, Costa Rica

5 Centro de Estudios Ambientales y de Biodiversidad, Universidad del Valle de Guatemala, Guatemala City, Guatemala

6 International Center for Tropical Agriculture (CIAT), CGIAR program on Climate Change Agriculture and Food Security (CCAFS), Cali, Colombia

7 American Association for the Advancement of Science (AAAS) Overseas Fellow serving at the United States Agency for International Development (USAID), Washington, DC, USA 
models for Central America. The results of this review provide insights into the expected impacts of climate change and suggest policy actions that can help minimize these impacts. Modeling indicates future climate-driven changes, often declines, in suitability for Central American crops. Declines in suitability for coffee, a central crop in the regional economy, are noteworthy. Ecosystem models suggest that climate-driven changes are likely at low- and high-elevation montane forest transitions. Modeling of vulnerability suggests that smallholders in many parts of the region have one or more vulnerability factors that put them at risk. Initial adaptation policies can be guided by these existing modeling results. At the same time, improved modeling is being developed that will allow policy action specifically targeted to vulnerable groups, crops, and locations. We suggest that more robust modeling of ecological responses to climate change, improved representation of the region in climate models, and simulation of climate influences on crop yields and diseases (especially coffee leaf rust) are key priorities for future research.

\section{Introduction}

Climate change is affecting agriculture, ecosystems, and livelihoods worldwide. Major shifts in the areas suitable for growing some of the world's major crops, such as wheat, corn, and coffee, are projected (Challinor et al. 2007). Plant and animal ranges are shifting to track suitable conditions as climate changes, resulting in reorganization of plant and animal communities and impacts on ecosystem services (Thomas et al. 2004). Where there are both agricultural and ecological changes, smallholder farmers may be particularly impacted, since they depend strongly on ecosystems and their services (Vermeulen et al. 2012; Ricketts et al. 2004). Policy makers need to take action to minimize the impacts of climate change on people and ecosystems, but policy is often formulated with little input from science (Rayner et al. 2005). Information at regional scales to provide context and at local scales to support building of adaptive capacity and inform locally tailored adaptation strategies are both important inputs to sound adaptation strategies.

Central America is one of the regions worldwide which is expected to suffer disproportionate agricultural and ecological impacts of climate change (Hannah et al. 2014). The region is particularly vulnerable because production of many of the principle crops is expected to decrease significantly with rising temperature. Most farmers are smallholders with limited adaptive capacity and there is high dependency on ecosystems and biodiversity for both onfarm (e.g., pollination, water provision) (Fischlin et al. 2007) and off-farm (e.g., tourism) income.

Regional modeling efforts are crucial to understanding the cumulative effects of climate change on agricultural and ecological sectors across the region and for providing context to national and local impact studies as well as policies and programs for food security, agriculture, climate change, and biodiversity conservation. The types of models that can contribute to this understanding include crop models, species distribution models, ecosystem models, hydrological models, and climate change models themselves. Modeling at local scales across such a diverse region is difficult and expensive. The methods used for local and regional studies are often the same or similar, so there are economies of scale in conducting crop, species, and ecosystem modeling at regional domains. Over a decade of regional modeling results now exist, so a synthesis of regional modeling results has great utility for informing local impact studies and polices to address these impacts. 
Here, we review the past decade of research on agricultural and ecological climate change impact models for Central America, in order to explore what the expected impacts of climate change will be on the region's ecosystems, agriculture, and smallholder farmers and to identify the key research and policy actions that will be needed to minimize these expected impacts. Specifically, we seek to answer the following questions: (1) What are the expected changes in climate in the region, based on historical climate data and regional models of future climate simulations?; (2) What are the major expected impacts of climate change on agriculture, ecosystems, and ecosystem services as shown by modeling?; (3) Are the existing climate models and models of expected impacts of climate change on agriculture, ecosystems, and ecosystem services sufficient for local impact assessment and development of adaptation policies?; (4) What are the key issues that policy makers need to address to minimize the expected impacts of climate change on the region?; and (5) In light of the above, what are the key research gaps that need to be filled? In the following five sections, we explore each of these questions in turn, beginning with observed and expected climate changes in the region.

\section{Observed regional climate trends}

The historical record of climate change in Central America reflects marked warming, but less certain changes in precipitation. The record spans nearly 100 years, but only the period from the early 1960s to the present has sufficient data for reliable analysis of trends (Aguilar et al. 2005). The region has warmed over the last four decades, but not uniformly (Hidalgo et al.

2015). Mean air surface temperature trends from global datasets at coarser resolution show a well-defined pattern of increasing temperature (IPCC 2013). The number of warm days and nights is increasing in the region, while cool days and nights decreased from 1961 to 2003 (Aguilar et al. 2005).

Precipitation trends in the region, on the other hand, are highly spatially variable and usually statistically insignificant (Fig. 1; Hidalgo 2013). There are inconsistencies in trends evidenced in different data sources that are not yet fully understood (Hidalgo et al. 2015). For example, satellite records show drying over Nicaragua (Neelin et al. 2006), but this drying is not reflected in the gridded data based on meteorological observations.

\section{Projected regional changes in climate}

Global climate models and regional climate models project the continuation of these trends into the future. Models of future temperature generally reflect warming across the region, while there is considerable model disagreement on magnitude and sign of future precipitation change. Nonetheless, many modeling studies project a warmer and drier climate in Central America by the end of the century (Fig. 2; Hidalgo et al. 2013).

Central America is a challenging environment for global climate models (general circulation models - GCMs). GCMs are unable to simulate well many of the synoptic influences that define Central American climate. Of particular importance is the subtropical high of the North Atlantic (Hidalgo et al. 2015). The El Niño Southern Oscillation (ENSO), the Caribbean Low Level Jet (CLLJ) (Amador 1998), and the Inter-tropical Convergence Zone (ITCZ) are other major determinants of climate in the region, and none are reliably simulated in most GCMs (Hidalgo and Alfaro 2014). For example, some GCMs reproduce fairly well important 
a) GPCP

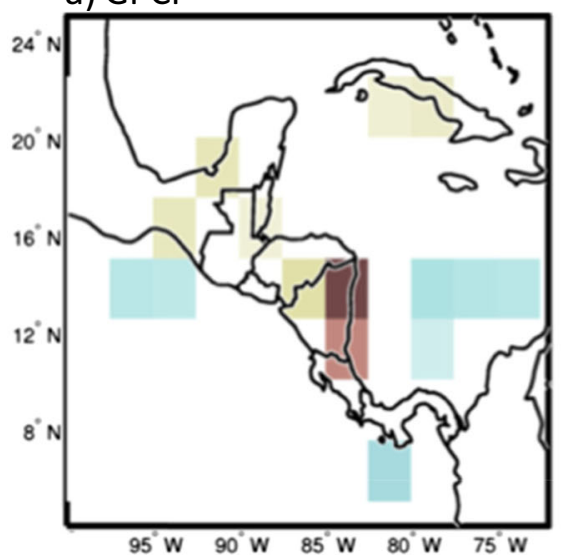

c) Rean.

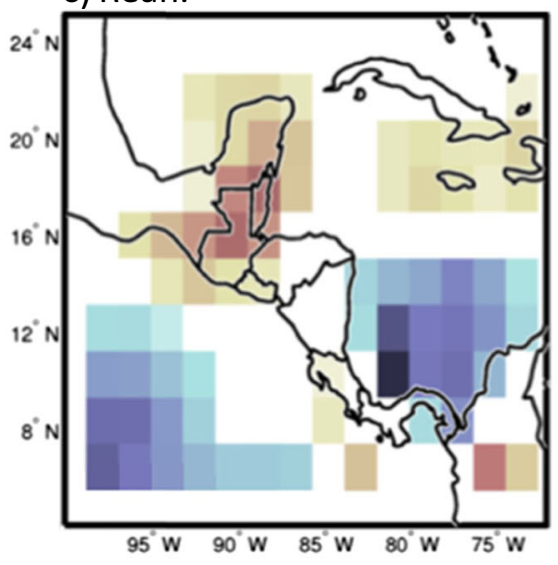

e) Pedreros

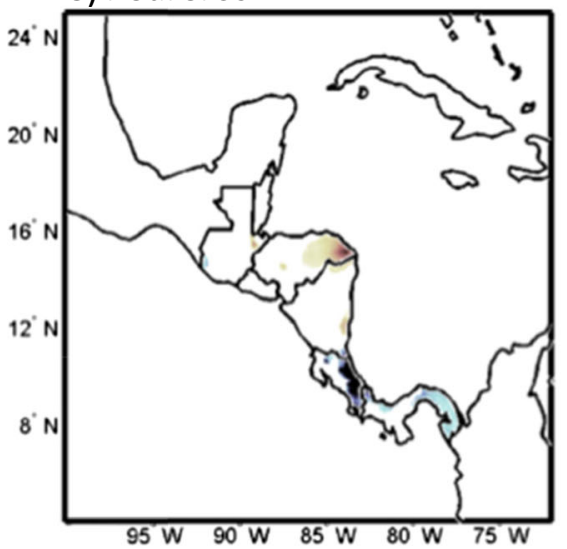

b) CMAP

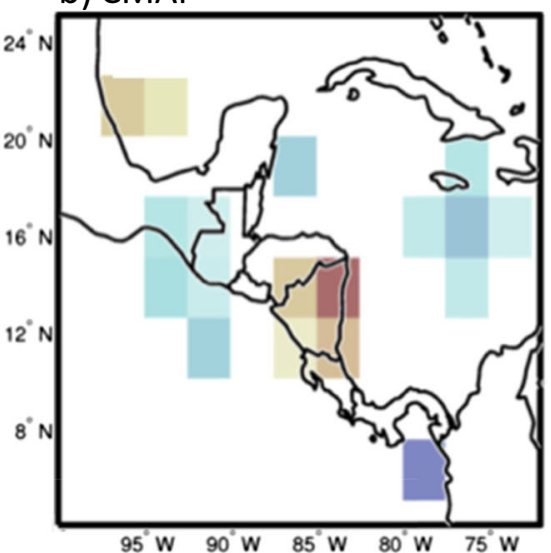

d) CHEN

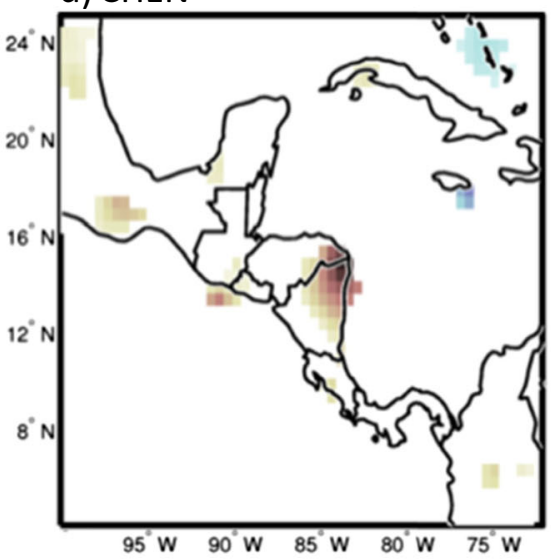

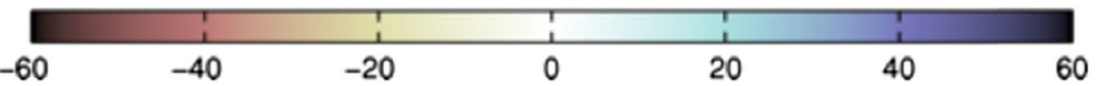


Fig. 1 Historical annual precipitation trends (1982-2005) in the region in millimeters per year. The panels correspond to the following databases. a Global Precipitation Climatology Project (GPCP; Adler et al. 2003). b CPC Merged Analysis of Precipitation (CMAP; Xie and Arkin 1997). c NCEP/NCAR reanalysis (Kalnay et al. 1996). d Chen et al. (2002) dataset. e Climate Hazards Group InfraRed Precipitation with Station data (CHIRPS; Pedreros et al. 2010). Only significant trends at the 95\% confidence are shown in color. Satellite precipitation indices show a decrease in precipitation over eastern Nicaragua. This drying is not reflected in the instrumental record (but there is no station data for that region) or a modeled reanalysis (which is constrained by temperature observations but not precipitation). From Hidalgo (2013)

characteristics of the climate in the region, such as the CLLJ, while others show significant biases (Hidalgo and Alfaro 2014).

Modeling of Central American climate is further complicated by the narrow landmass of the region (which is very small relative to the horizontal resolution of most GCMs) sandwiched between two major oceanic influences. However, GCM resolutions are improving, and regional climate models are becoming available which are able to better represent the isthmus and its topography as well as land use (Chou et al. 2014). Increased resolution in GCMs could enhance simulation of ENSO and other synoptic influences (Hidalgo and Alfaro 2014).

However, carefully applied, GCM simulations still have utility for this region (Hidalgo and Alfaro 2014). A detailed selection of models is necessary in climate change impact studies using GCMs. The warming trend in historical observations, GCM, and RCM simulations is robust, paving the way for important insight in modeling of crops and ecosystems.

\section{Projected impacts of climate change on agriculture}

Agriculture is a major economic activity in Central America, and climate change is expected to significantly impact agriculture across the region (Magrin et al. 2007). Therefore, it is extremely important to understand the impacts of climate change on crop suitability and productivity and on the incidence of agricultural pests and diseases, as well as the impacts of those changes on socioeconomic variables. This understanding can inform the development of adaptation policies and the identification of adaptation recommendations.

Fig. 2 Projected temperature change across $36 \mathrm{GCM}$ simulations to 2070 (RCP8.5) relative to historical baseline (changes in degrees C). From Imbach et al. (2012)

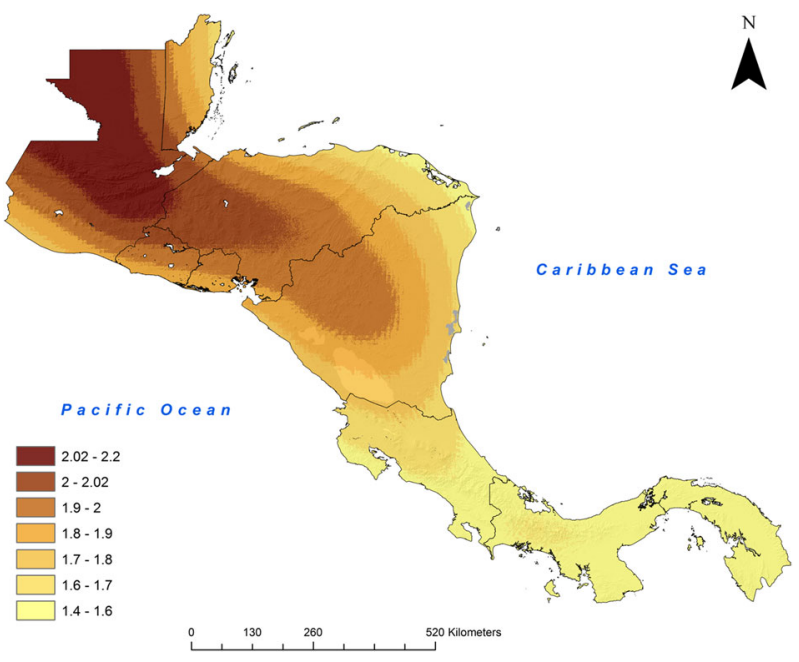


In Central America, the most important cash and subsistence crops in terms of cultivated area are maize $(34 \%)$, coffee $(16 \%)$, beans $(14 \%)$, sugar cane $(8.4 \%)$, rice $(5.8 \%)$, sorghum $(4.9 \%)$, cocoa $(0.5 \%)$, plantain $(1.1 \%)$, and cassava $(0.9 \%)$, according to national agricultural censuses (Bouroncle et al. 2016). Of these crops, coffee is the most studied using impact models, with maize the second most studied, followed by other crops.

Coffee is among the most important cash crops in the region, and an array of modeling studies suggest that most of the countries in the region will lose yield and area suitable for coffee cultivation due to climate change (Table 1). Several regional studies of the projected impacts of climate change on coffee are available, and all point to an overall and severe decrease in suitability for coffee (Baca et al. 2014; Ovalle-Rivera et al. 2015, Laderach et al. 2013, Bunn et al. 2015). El Salvador and Costa Rica have the highest percentage of their land affected by decreases in suitability of $40 \%$ or more, while Guatemala and Honduras are projected to experience lower losses (Baca et al. 2014, Laderach et al. 2013). Temperature is what most likely determines these severe and negative changes in suitability for coffee (Ovalle-Rivera et al. 2015) as this crop has a relatively small thermal range compared to other crops (FAO 2015). One study of coffee yield under climate change shows a reduction in yield of between $6.4 \%$ in 2020 and 38\% in 2100 in all Central American countries (CEPAL y CAC/ SICA 2014a).

Among important subsistence crops (Table 2), declines in maize suitability are noted. Modeling of maize indicates a projected decline in yield across most parts of the region (Schmidt et al. 2012; Ordaz et al. 2013; CEPAL y CAC/SICA 2014a, b; Gourdji et al. 2015). National modeling efforts support the Central America-wide regional models (Confalonieri et al. 2012), showing declines of up to $4 \%$ in harvested area in Nicaragua (Gourdji et al. 2015), up to $22 \%$ in Belize (Tzul et al. 1997), and up to $34 \%$ in yield for El Salvador, Guatemala, Honduras, and Nicaragua (Schmidt et al. 2012).

Less is known about how the suitability and productivity of beans, cocoa, cassava, sorghum, and rice will be affected by climate change in the region. Future yield projections for beans vary, with one regional study showing a decrease in yield of up to $19.3 \%$ in Central America (CEPAL y CAC/SICA 2014a, b), whereas subnational and national studies show an increase (Schmidt et al. 2012; Pazos 2004) or decrease (Gourdji et al. 2015; Tzul et al. 1997) in yield. A global study (Friedman, unpublished) on cocoa shows that on average, the Caribbean basin of Central America will lose areas of suitability. For cassava, one study projects an overall yield decrease from 1 to $10 \%$ across most of its current distribution (Ceballos et al. 2011). For sorghum, decreases of up to $15 \%$ in suitable area are projected for the Pacific lowlands and increases of up to $40 \%$ are expected in mountainous areas and on the Atlantic Coast (Ramírez-Villegas et al. 2013). Decreases in yield are also projected for rice across all Central American countries (Confalonieri et al. 2012; CEPAL y CAC/SICA 2014b; Tzul et al. 1997).

These modeling results are complemented by the strong perception among smallholder farmers in the region that climate change and variability are already reducing crop productivity, causing crop losses, and affecting water availability (Tucker et al. 2009; Eakin et al. 2013). There have been significant changes in the susceptibility of agriculture to pests and diseases related to climate change (Rosenzweig et al. 2001), including coffee leaf rust which has devastated production in the region in recent years and which is influenced by changing climatic conditions, among other factors (Avelino et al. 2015). Extreme weather eventsparticularly strong storms and hurricanes - have reduced crop yields, increased soil erosion, and resulted in floods and landslides (UNEP-ECLAC 2010). The loss of agricultural 
Table 1 Studies assessing impacts of climate change on cash crops grown by smallholder farmers in Central America

\begin{tabular}{|c|c|c|c|c|c|c|c|}
\hline $\begin{array}{l}\text { Crop } \\
\text { (\% of } \\
\text { cover } \\
\text { area) }\end{array}$ & $\begin{array}{l}\text { Target } \\
\text { countries }\end{array}$ & Reference & Suitability & Yield & Scope & Resolution & $\begin{array}{l}\text { Temporal } \\
\text { scale }\end{array}$ \\
\hline \multirow[t]{5}{*}{$\begin{array}{r}\text { Coffee } \\
(16)\end{array}$} & $\begin{array}{l}\text { El Salvador, } \\
\text { Nicaragu- } \\
\text { a, and } \\
\text { Guatema- } \\
\text { la }\end{array}$ & $\begin{array}{l}\text { Baca et al. } \\
\quad(2014)\end{array}$ & $\begin{array}{l}\text { Reduction of } 40 \% \text { or } \\
\text { more in suitability } \\
\text { of a high } \\
\text { percentage of land } \\
\text { in El Salvador and } \\
\text { Nicaragua, and up } \\
\text { to } 20 \% \text { in the } \\
\text { highest percentage } \\
\text { of land in } \\
\text { Guatemala }\end{array}$ & & $\mathrm{N}, \mathrm{SN}$ & $\mathrm{H}$ & 2050 \\
\hline & $\begin{array}{l}\text { Costa Rica, } \\
\text { Guatema- } \\
\text { la, and } \\
\text { Honduras }\end{array}$ & $\begin{array}{l}\text { Ovalle-Rivera } \\
\text { et al. } \\
\text { (2015) }\end{array}$ & $\begin{array}{l}\text { Reduction of } 20 \% \text { in } \\
\text { suitable areas in } \\
\text { Costa Rica, } 19 \% \text { in } \\
\text { Guatemala, and } \\
27 \% \text { in Honduras }\end{array}$ & & Global & $\mathrm{H}$ & 2050 \\
\hline & $\begin{array}{l}\text { El Salvador, } \\
\text { Nicaragu- } \\
\text { a, Costa } \\
\text { Rica, } \\
\text { Guatema- } \\
\text { la, and } \\
\text { Honduras }\end{array}$ & $\begin{array}{l}\text { Läderach et al. } \\
\qquad(2013)\end{array}$ & $\begin{array}{l}\text { Reduction of } 40 \% \text { or } \\
\text { more in suitability } \\
\text { of a high } \\
\text { percentage of land } \\
\text { in El Salvador, } \\
\text { Nicaragua, and } \\
\text { Costa Rica, } \\
\text { between } 20 \text { and } \\
40 \% \text { in Honduras, } \\
\text { and up to } 20 \% \text { in } \\
\text { Guatemala }\end{array}$ & & $\mathrm{R}, \mathrm{N}$ & $\mathrm{H}$ & 2050 \\
\hline & $\begin{array}{l}\text { Central } \\
\text { America }\end{array}$ & $\begin{array}{c}\text { Bunn et al. } \\
\text { (2015) }\end{array}$ & $\begin{array}{l}\text { Reductions in } \\
\text { suitability in all } \\
\text { countries. Small } \\
\text { areas in Guatemala, } \\
\text { Honduras, and } \\
\text { Costa Rica } \\
\text { becoming slightly } \\
\text { more suitable }\end{array}$ & & $\mathrm{N}$ & $\mathrm{H}$ & 2050 \\
\hline & $\begin{array}{l}\text { Central } \\
\text { America }\end{array}$ & $\begin{array}{l}\text { CEPAL y } \\
\text { CAC/SICA } \\
(2014 a)\end{array}$ & & $\begin{array}{l}\text { Reduction } \\
\text { between } \\
6.4 \% \text { in } \\
2020 \text { and } \\
38.3 \% \text { in } \\
2100 \text { in } \\
\text { all } \\
\text { countries }\end{array}$ & $\mathrm{R}$ & $\mathrm{H}$ & $\begin{array}{l}2020 \\
2050 \\
2070 \\
2100\end{array}$ \\
\hline $\begin{array}{r}\text { Citrus } \\
(22)\end{array}$ & Belize & $\begin{array}{c}\text { Santos and } \\
\text { Garcia } \\
(2008)\end{array}$ & & $\begin{array}{l}\text { Reduction of } \\
3 \% \text { by } \\
2028 \text { and } \\
\text { a } 5 \% \\
\text { reduction } \\
\text { by } 2050\end{array}$ & $\mathrm{~N}$ & $\begin{array}{l}\text { Not } \\
\text { speci- } \\
\text { fied }\end{array}$ & $\begin{array}{l}2028, \\
2050\end{array}$ \\
\hline $\begin{array}{c}\text { Cacao } \\
\text { (1) }\end{array}$ & Nicaragua & $\begin{array}{r}\text { Martinez } \\
\text { (2012) }\end{array}$ & $\begin{array}{l}\text { Decrease in overall } \\
\text { suitability in all } \\
\text { Nicaragua }\end{array}$ & & $\mathrm{SN}, \mathrm{N}$ & $\mathrm{H}$ & 2050 \\
\hline
\end{tabular}


Table 1 (continued)

\begin{tabular}{|c|c|c|c|c|c|c|c|}
\hline $\begin{array}{l}\text { Crop } \\
\text { (\% of } \\
\text { cover } \\
\text { area) }\end{array}$ & $\begin{array}{l}\text { Target } \\
\text { countries }\end{array}$ & Reference & Suitability & Yield & Scope & Resolution & $\begin{array}{l}\text { Temporal } \\
\text { scale }\end{array}$ \\
\hline & $\begin{array}{l}\text { Central } \\
\text { America }\end{array}$ & $\begin{array}{c}\text { Friedman } \\
\text { (unpub- } \\
\text { lished) }\end{array}$ & $\begin{array}{l}\text { Caribbean basin will } \\
\text { lose areas of } \\
\text { optimal suitability } \\
\text { in } 2020 \text {, and areas } \\
\text { will be even larger } \\
\text { in } 2050\end{array}$ & & $\mathrm{R}$ & $\mathrm{L}$ & $\begin{array}{l}2020, \\
2050\end{array}$ \\
\hline
\end{tabular}

$N$ national, $R$ regional, $S N$ subnational, $H<5 \mathrm{~km}, M 5-10 \mathrm{~km}, L>10 \mathrm{~km}$

productivity has had important impacts on smallholder farmers, resulting in lower incomes, reduced food security, malnutrition and migration of farmers to other areas (Castellanos et al. 2012; Robalino et al. 2015).

\section{Projected changes in biodiversity and ecosystem services due to climate change}

Climate change will affect ecosystems and the provision of ecosystem services such as clean water or pollination to a wide range of users across a broad range of sectors in Central America. Those in poor rural areas are expected to suffer the largest impacts due to their strong dependence on ecosystems and ecosystem services (Fischlin et al. 2007).

Assessments of future ecosystem change in Central America project an expansion of drier ecosystem types (e.g., dry forests) eastward expanding from Pacific lowlands toward the more humid Caribbean. Leaf area index is projected to decline across all ecosystems, indicating changes in forest canopy density, if not forest type (Imbach et al. 2012). Parts of central Honduras and Guatemalan highlands might lose the potential to sustain tree cover due to drier conditions (Imbach et al. 2012). Modeling for Costa Rica using Holdridge life zones shows higher sensitivity of ecosystems in tropical lowlands and highland areas, with less sensitivity in ecosystems at intermediate elevations (Enquist 2002).

There are already plot-level observation studies that indicate these changes are underway. For example, studies at Panama's Barro Colorado Island show an increasing representation of drought-tolerant species (Feeley et al. 2011). Similarly, forests in northeastern Costa Rica have grown more slowly due to lower precipitation and increased minimum temperatures (Clark et al. 2010). Dry tropical forests in Costa Rica's northern Pacific region are showing increases in deciduous canopy species in response to drying (Enquist and Enquist 2011).

Studies of climate change impacts on biodiversity suggest that tropical lowland species will suffer the greatest range shifts and loss of range, causing local extinctions or decreasing lowland diversity. This is due to upslope range migrations in response to warmer climate conditions and biotic attrition (higher numbers of emigration than immigration species) (Feeley and Silman 2010). However, some species (e.g., Pinus patula and Pinus tecunumanii) might experience a positive effect from climate change, expanding their current distributional ranges (van Zonneveld et al. 2009). The capacity that species may have to disperse and reach 
Table 2 Studies assessing impacts of climate change on subsistence crops grown by smallholder farmers in Central America

\begin{tabular}{|c|c|c|c|c|c|c|c|}
\hline $\begin{array}{l}\text { Crop ( } \% \\
\text { of cover } \\
\text { area) }\end{array}$ & $\begin{array}{l}\text { Target } \\
\text { countries }\end{array}$ & Reference & Suitability & Yield & Scope & Resolution & $\begin{array}{l}\text { Temporal } \\
\text { scale }\end{array}$ \\
\hline \multirow[t]{6}{*}{$\begin{array}{r}\text { Maize } \\
(34)\end{array}$} & Honduras & Pazos (2004) & & $\begin{array}{l}\text { Reduction in } \\
\text { all } 6 \\
\text { scenarios, } \\
\text { except B2b }\end{array}$ & $\mathrm{SN}$ & $\begin{array}{l}\text { Not } \\
\text { speci- } \\
\text { fied }\end{array}$ & $\begin{array}{l}\text { Not } \\
\text { speci- } \\
\text { fied }\end{array}$ \\
\hline & Nicaragua & $\begin{array}{l}\text { Gourdji et al. } \\
\text { (2015) }\end{array}$ & & $\begin{array}{l}\text { Reduction of } \\
4 \% \text { per } \\
\text { decade on } \\
\text { harvested } \\
\text { area }\end{array}$ & $\mathrm{N}$ & $\mathrm{H}$ & $\mathrm{CV}$ \\
\hline & $\begin{array}{l}\text { Central } \\
\text { America }\end{array}$ & $\begin{array}{l}\text { CEPAL y } \\
\text { CAC/SICA } \\
(2014 b)\end{array}$ & & $\begin{array}{l}\text { Reductions in } \\
\text { all } \\
\text { countries } \\
\text { between } \\
4 \% \text { in } 2020 \\
\text { and } 17.2 \% \\
\text { in } 2100 \text { in } \\
\text { Central } \\
\text { America }\end{array}$ & $\mathrm{R}$ & $\mathrm{H}$ & $\begin{array}{l}2020, \\
2050, \\
2070, \\
2100\end{array}$ \\
\hline & Belize & Tzul et al. (1997) & & $\begin{array}{l}\text { Reduction } \\
\text { between } 17 \\
\text { and } 22 \%\end{array}$ & $\mathrm{~N}$ & $\begin{array}{l}\text { Not } \\
\text { speci- } \\
\text { fied }\end{array}$ & $\begin{array}{l}2060 \\
2080-2- \\
100\end{array}$ \\
\hline & $\begin{array}{l}\text { El Salvador, } \\
\text { Guatem- } \\
\text { ala, } \\
\text { Hondur- } \\
\text { as, and } \\
\text { Nicara- } \\
\text { gua }\end{array}$ & $\begin{array}{l}\text { Schmidt et al } \\
\text { (2012) }\end{array}$ & & $\begin{array}{l}\text { Losses up to } \\
34 \% \text { in El } \\
\text { Salvador, } \\
\text { Guatemala, } \\
\text { Honduras, } \\
\text { and } \\
\text { Nicaragua }\end{array}$ & $\mathrm{N}, \mathrm{SN}$ & $\mathrm{H}$ & 2025 \\
\hline & $\begin{array}{l}\text { Central } \\
\text { America }\end{array}$ & $\begin{array}{l}\text { Confalonieri et al. } \\
\text { (2012) }\end{array}$ & & $\begin{array}{l}\text { Reduction } \\
\text { between } 20 \\
\text { and } 50 \% \\
\text { without } \\
\text { adaption } \\
\text { measures } \\
\text { and } \\
\text { between } 15 \\
\text { and } 25 \% \\
\text { with } \\
\text { adaption } \\
\text { measures in } \\
\text { all } \\
\text { countries }\end{array}$ & $\mathrm{R}, \mathrm{N}$ & $\mathrm{L}$ & 2020 \\
\hline \multirow[t]{2}{*}{$\begin{array}{r}\text { Beans } \\
(14)\end{array}$} & Guatemala & $\begin{array}{l}\text { Eitzinger et al. } \\
\text { (2011) }\end{array}$ & $\begin{array}{l}\text { Small increase } \\
\text { in } 2030 \text { and } \\
2050\end{array}$ & & $\mathrm{SN}, \mathrm{N}$ & $\begin{array}{l}\text { Not } \\
\text { speci- } \\
\text { fied }\end{array}$ & 2030,2050 \\
\hline & $\begin{array}{l}\text { E1 Salvador, } \\
\text { Hondur- } \\
\text { as, } \\
\text { Nicarag- } \\
\text { ua, and }\end{array}$ & $\begin{array}{l}\text { Schmidt et al. } \\
\text { (2012) }\end{array}$ & & $\begin{array}{l}\text { Changes } \\
\text { between }-7 \\
\text { and }+14 \% \\
\text { in El } \\
\text { Salvador, } \\
\text { Honduras, }\end{array}$ & $\mathrm{SN}, \mathrm{N}$ & $\mathrm{H}$ & 2025 \\
\hline
\end{tabular}


Table 2 (continued)

\begin{tabular}{|c|c|c|c|c|c|c|c|}
\hline $\begin{array}{l}\text { Crop (\% } \\
\text { of cover } \\
\text { area) }\end{array}$ & $\begin{array}{l}\text { Target } \\
\text { countries }\end{array}$ & Reference & Suitability & Yield & Scope & Resolution & $\begin{array}{l}\text { Temporal } \\
\text { scale }\end{array}$ \\
\hline & $\begin{array}{l}\text { Guate- } \\
\text { mala }\end{array}$ & & & $\begin{array}{l}\text { and } \\
\text { Nicaragua } \\
\text { and an } \\
\text { increase of } \\
4 \% \text { in } \\
\text { Guatemala }\end{array}$ & & & \\
\hline & Honduras & Pazos (2004) & & $\begin{array}{l}\text { Increment in } \\
\text { most } \\
\text { scenarios }\end{array}$ & $\mathrm{SN}$ & $\begin{array}{l}\text { Not } \\
\text { speci- } \\
\text { fied }\end{array}$ & $\begin{array}{l}\text { Not } \\
\text { speci- } \\
\text { fied }\end{array}$ \\
\hline & Nicaragua & $\begin{array}{l}\text { Gourdji et al. } \\
\text { (2015) }\end{array}$ & & $\begin{array}{l}\text { Reduction of } \\
5 \% \text { per } \\
\text { decade on } \\
\text { harvested } \\
\text { areas }\end{array}$ & $\mathrm{N}$ & $\mathrm{H}$ & $\mathrm{CV}$ \\
\hline & Belize & Tzul et al. (1997) & & $\begin{array}{l}\text { Reduction } \\
\text { between } 14 \\
\text { and } 19 \%\end{array}$ & $\mathrm{~N}$ & $\begin{array}{l}\text { Not } \\
\text { speci- } \\
\text { fied }\end{array}$ & $\begin{array}{l}2060, \\
2080-2- \\
100\end{array}$ \\
\hline & $\begin{array}{l}\text { Central } \\
\text { America }\end{array}$ & $\begin{array}{l}\text { CEPAL y } \\
\text { CAC/SICA } \\
(2014 b)\end{array}$ & & $\begin{array}{l}\text { Reduction } \\
\text { between } \\
2.8 \text { and } \\
19.3 \% \text { in } \\
\text { Central } \\
\text { America. } \\
\text { Guatemala } \\
\text { shows a } \\
1.5 \% \\
\text { increase. }\end{array}$ & $\mathrm{R}$ & $\mathrm{H}$ & $\begin{array}{l}2020, \\
2050, \\
2070, \\
2100\end{array}$ \\
\hline $\begin{array}{c}\text { Cassava } \\
\text { (1) }\end{array}$ & $\begin{array}{l}\text { Central } \\
\text { America }\end{array}$ & $\begin{array}{l}\text { Ceballos et al. } \\
\text { (2011) }\end{array}$ & & $\begin{array}{l}\text { Reduction } \\
\text { between } 1 \\
\text { and } 10 \% \text { in } \\
\text { all } \\
\text { countries }\end{array}$ & $\mathrm{R}$ & $\begin{array}{l}\text { Not } \\
\text { speci- } \\
\text { fied }\end{array}$ & 2020 \\
\hline $\begin{array}{l}\text { Sorghum } \\
\text { (5) }\end{array}$ & $\begin{array}{l}\text { Central } \\
\text { America }\end{array}$ & $\begin{array}{l}\text { Ramírez-Villegas } \\
\text { et al. (2013) }\end{array}$ & $\begin{array}{l}\text { Decreases up } \\
\text { to } 15 \% \text { in } \\
\text { the Pacific } \\
\text { lowlands. } \\
\text { Increases } \\
\text { up to } 40 \% \\
\text { in } \\
\text { mountain- } \\
\text { ous areas } \\
\text { and on the } \\
\text { Atlantic } \\
\text { Coast }\end{array}$ & & Global & $\mathrm{H}$ & 2030 \\
\hline Rice (6) & $\begin{array}{l}\text { Central } \\
\text { America }\end{array}$ & $\begin{array}{l}\text { Confalonieri et al. } \\
\text { (2012) }\end{array}$ & & $\begin{array}{l}\text { Reduction } \\
\text { between } 15 \\
\text { and } 25 \% \\
\text { without } \\
\text { adaptation } \\
\text { measures } \\
\text { and } \\
\text { between } 5\end{array}$ & $\mathrm{R}, \mathrm{N}$ & $\mathrm{L}$ & 2050 \\
\hline
\end{tabular}


Table 2 (continued)

\begin{tabular}{|c|c|c|c|c|c|c|c|}
\hline $\begin{array}{l}\text { Crop ( } \% \\
\text { of cover } \\
\text { area) }\end{array}$ & $\begin{array}{l}\text { Target } \\
\text { countries }\end{array}$ & Reference & Suitability & Yield & Scope & Resolution & $\begin{array}{l}\text { Temporal } \\
\text { scale }\end{array}$ \\
\hline & & & & $\begin{array}{l}\text { and } 15 \% \\
\text { with } \\
\text { adaptation } \\
\text { measures in } \\
\text { all } \\
\text { countries }\end{array}$ & & & \\
\hline & $\begin{array}{l}\text { Central } \\
\text { America }\end{array}$ & $\begin{array}{l}\text { CEPAL y } \\
\text { CAC/SICA } \\
(2014 b)\end{array}$ & & $\begin{array}{l}\text { Reduction } \\
\text { between } \\
7 \%(2020) \\
\text { and } 30.2 \% \\
(2100) \text { in } \\
\text { all coun- } \\
\text { tries }\end{array}$ & $\mathrm{R}$ & $\mathrm{H}$ & $\begin{array}{r}2020 \\
2050 \\
2070 \\
2100\end{array}$ \\
\hline & Belize & Tzul et al. (1997) & & $\begin{array}{l}\text { Reduction } \\
\text { between } 10 \\
\text { and } 14 \%\end{array}$ & $\mathrm{~N}$ & $\begin{array}{l}\text { Not } \\
\text { speci- } \\
\text { fied }\end{array}$ & $\begin{array}{l}2060 \\
2080-2- \\
100\end{array}$ \\
\hline
\end{tabular}

$N$ national, $R$ regional, $S N$ subnational, $H<5 \mathrm{~km}, M 5-10 \mathrm{~km}, L>10 \mathrm{~km}$

ideal climatic conditions will depend on their dispersal ability and ability to access biological corridors, mainly altitudinal pathways (Imbach et al. 2013).

Modeling of impacts on ecosystem services has focused on multinational modeling of vegetation and water availability (Imbach et al. 2015). These models project that runoff is projected to decrease substantially across Central America, with at least $20 \%$ likely reduction over $61 \%$ of the region, due primarily to temperature impacts on evapotranspiration (Imbach et al. 2012). Similar trends have been found in models of water availability under climate change at the catchment scale. For example, models show up to $24 \%$ reduction in tri-national catchments (over El Salvador, Honduras, and Guatemala) (Maurer et al. 2009); $70 \%$ in central Nicaragua (Palmer et al. 2008), and mixed trends (+40 to $-50 \%)$ in runoff in 2100 precipitation change scenarios over Panama (Fabrega et al. 2013). Increased drought frequency is also expected across the region (Hidalgo et al. 2013). Since most smallholder farmers depend to some extent on surface water, these changes in water availability have serious ramifications for their livelihoods.

\section{Improving modeling linkages to adaptation and policy}

Regional models reviewed here show major potential declines in crop suitability and yield, changes in species and ecosystem distributions, and reduction in water availability due to climate change. These models show that the suitability of some of the most important crops in the region, coffee and maize, may undergo declines substantial enough to have major economic consequences. Redistribution of species and ecosystems may result in extinctions and loss of tourism revenue. Both smallholder and ecosystem changes may be compounded by decreases in ecosystem services driven by climate change, particularly reductions in water runoff (Eitzinger et al. 2013). 
When appropriately combined with assessments of the adaptive capacity of rural livelihoods at community and on-farm levels to assess vulnerability, these modeling results can be used to identify a suite of adaptation strategies and policies. On- and off-farm adaptation strategies should help reduce the vulnerability of smallholder farmers to decreasing subsistence and cash crop suitability, and to changes in the ecosystem services on which farmers rely. Protected areas' location and management can be improved to reduce risk of extinctions and loss of ecosystem services, especially in upland areas where increases of suitability for coffee and some other crops are expected. Policies supporting these strategies span a range of novelty, from reinforcing the importance of policies already in place to implementing completely new actions.

Diversification in smallholder farming systems can help farmers adapt to declines in coffee and subsistence crops with income from other crops or varieties that may be increasing in yield or suitability as climate changes. Areas for these on-farm actions can be targeted for diversification based on results of regional modeling, for instance in areas where particular crops will experience a decrease in suitability and/or yield.

On-farm soil moisture conservation practices could largely offset the projected negative impacts of climate change, particularly on maize yield (Schmidt et al. 2012). Those soil management practices, such as retaining plant residue on the soil surface and mulching, can also reduce the vulnerability of farmers to expected decreases in water runoff and availability and provide off-farm benefits for improved water quality and regulation to downstream users. Those practices could be implemented in areas where maize yield and/or where water runoff and availability are expected to decrease, which are highlighted by results of existing regional modeling. Off-farm adaptation strategies related to the protection, restoration, and sustainable management of key ecosystems and biodiversity can help maintain ecosystem services that small farmers rely on, such as crop pollination and pest control, as climate changes.

Shifting species and ecosystem locations can be compensated through strategies that represent all species and ecosystems in protected areas in both their present and likely future locations. A strategy of revising protected areas' boundaries and locations based on climate change modeling can help conserve species and ecosystem services (see Fung et al. this issue).

Adaptation strategies should be supported by policies that help strengthen regional extension services to farmers, environmental planning capacities, and that afford smallholder farmers improved access to credit. Extension services are crucial to targeted improvement of on-farm diversification and soil moisture-retaining practices. Government extension services in the region have declined, so support for rebuilding government services or supplementing them with NGO on-farm extension are important in implementing strategies for climate adaptation.

Access to credit is key for farmers and cooperatives to implementing these adaptation strategies, as diversification and soil moisture practices often incur up-front costs in return for long-term climate adaptation and income returns. Capacity building and information sharing through extension services alone will be insufficient to help farmers adapt if farmers and cooperatives do not have sufficient financial resources to help support or improved practices.

National environmental planning can be improved by incorporating results of agricultural and biological models. Planning can be improved by drawing on existing regional modeling studies, collaborating with NGOs and research institutions on additional studies, and improving government or NGO in-house spatial planning and modeling capabilities. This improved 
spatial planning can reduce extinctions, improve conservation of areas key to pollinators and watersheds, and protect ecosystem services important to the livelihoods of farmers. Improved spatial planning for climate change can help target diversification, soil moisture practices, and other adaptation strategies to communities and areas most in need and improve the provision of on- and off-farm services (e.g., Bouroncle et al. 2016; Fung et al. this issue; Holland et al. this issue).

\section{Future research priorities}

Important research priorities emerge from this analysis. First, advanced crop models can build on the robust set of early results. While there are suitability analyses for the most important crops in the region, there is still a need for more sophisticated yield models for most major crops and for suitability and yield modeling for the less well-studied crops. Yield analyses are more data intensive, but the data exist for many parts of the region and additional investment is warranted to help confirm or test suitability model results. This process is already underway for maize, but similar efforts are needed in other key crops. Suitability and yield models are needed that focus on actual and likely cultivated areas (rather than the whole region regardless of land use), to get a better sense of the regional significance of area and yield losses. To plan diversification, modeling is needed to identify which crops may replace existing crops in areas where suitability for existing crops significantly declines due to climate change.

Second, improved biological models are essential to understanding environmental change in the region, particularly changes in species extinctions and ecosystem services. Virtually no models exist of species' dispersal relative to range shifts due to climate change in the region and the vegetation type models that exist are relatively simple. Building on understanding of species and ecosystem movements, more sophisticated models can explore effects on ecosystem processes, including ecosystem services and inter-species interactions. More sophisticated models on the expected impacts of climate change on the region's rich biodiversity are needed to inform protected area management and to ensure countries' national biodiversity strategies adequately address the threat of climate change.

Third, more information is needed on expected changes in water availability across the region's watersheds and the associated impacts on agriculture, communities, and other sectors. Such information is critical for informing watershed management plans, water policies, and payments for ecosystem services, among other policies. Modeling needs to include impacts on groundwater and interactions between surface and groundwater withdrawals of particular importance for the drier Pacific watershed.

Fourth, models are needed that place local to regional yield changes in context with global changes in yield and market price. Without understanding global price changes due to climate change, it is impossible to develop informed regional or national policy strategies that will help maintain and increase farmer incomes. For instance, declining local coffee suitability does not automatically equate to lowered incomes if global prices are rising (due to global suitability declines). Strategies to support existing crops or diversification will be most effective where they draw on information from models that put local change into global context.

Finally, much more information is needed on how climate change will affect key diseases and pests, especially coffee leaf rust, a disease that led to a $16 \%$ decrease of the region's coffee production in the 2012-2013 harvest (Avelino et al. 2015). The impacts of climate change are 
likely to be more heavily impacted by these factors than by the direct effects of climate on suitability or yield. Understanding complex climate influences on major pests and diseases is a major research priority.

\section{Conclusion}

Our synthesis highlights that climate change in Central America is projected to result in declines in crop suitability for many of the major smallholder crops, significant changes in natural ecosystems, and associated changes in the provision of ecosystem services, particularly water availability. These changes will have important impacts on the region's smallholder farmers, affecting their income, food security and livelihood strategies, and on the agricultural sector biodiversity and national economies more generally.

Flexible adaptation strategies are needed that can address both agricultural and ecological dimensions of change. Flexible strategies are important because of the uncertainty surrounding precipitation change in the region and potential discrepancies between short-term variability and longer term trends. Until GCMs can better represent the sub-tropical high of the North Atlantic, ENSO, and other teleconnections, adaptation must be prepared for the consequences of either increases (flooding) or decreases (drought) in precipitation. Addressing agricultural and ecological adaptation in an integrated manner is important because of the interconnectedness of ecosystem services and smallholder agriculture in the region.

Intermediaries are needed to bridge the gap between modeling of projected climate impacts and action on the ground. Government policies and programs should reach out to small farmers and help them adapt to climate change, by strengthening the ability of extension services to use modeling results, providing information on likely crop and ecosystem changes and their global context, promoting sustainable agricultural practices that have adaptation benefits, and providing incentives that reward building farm and ecosystem resilience. NGOs working directly with farmers play a valuable role in helping realize the full potential of adaptation strategies on the ground, particularly in light of the weakening of government agricultural extension services. Finally, researchers and modelers need to produce fine-scale models relevant to building adaptation capacity on-farm and climate-sensitive practices. These may be conceptual models with simple data needs, rather than GCM-driven simulations. As evidence from results stemming from ground-based measurements and modeling efforts, major climate-driven changes are occurring in the region, making it crucial for scientists and practitioners to work together to find flexible solutions.

Acknowledgments This work was conducted as part of the CASCADE project (Ecosystem based Adaptation for Smallholder Subsistence and Coffee Farmers in Central America). The project is part of the International Climate Initiative (ICI). German Federal Ministry for the Environment, Nature Conservation, Building and Nuclear Safety (BMUB) supports this initiative on the basis of a decision adopted by the German Bundestag. Participation by JPL in this activity was supported by an American Association for the Advancement of Science (AAAS) Science and Technology Policy Overseas Fellowship served at the USAID/El Salvador Central America Regional Program. The views expressed in this document reflect the personal opinions of the author and are entirely the author's own. They do not necessarily reflect the opinions of the US Agency for International Development (USAID), the United States Government, or the AAAS. USAID and AAAS are not responsible for the accuracy of any information supplied herein. PI received financial support from AC3 project from the International Development Research Centre (IDRC) Canada. EA and HH also thank the UCR grants 805-B6-143 
(UCR, CONICIT-MICITT), 805-B4-227, and 805-B3-600. The participation of PL was supported by CGIAR Research Program on Climate Change, Agriculture and Food Security (CCAFS).

Open Access This article is distributed under the terms of the Creative Commons Attribution 4.0 International License (http://creativecommons.org/licenses/by/4.0/), which permits unrestricted use, distribution, and reproduction in any medium, provided you give appropriate credit to the original author(s) and the source, provide a link to the Creative Commons license, and indicate if changes were made.

\section{References}

Aguilar E, Peterson TC, Ramirez Obando P, Frutos R, Retana JA, Solera M, Soley J, Gonzalez Garcia I, Araujo RM, Rosa Santos A, Valle VE, Brunet M, Aguilar L, Alvarez L, Bautista M, Castanon C, Herrera L, Ruano E, Sinay JJ, Sanchez E, Hernandez Oviedo GI, Obed F, Salgado JE, Vazquez JL, Baca M, Gutierrez M, Centella C, Espinosa J, Martinez D, Olmedo B, Ojeda Espinoza CE, Nunez R, Haylock M, Benavides H, Mayorga R (2005) Changes in precipitation and temperature extremes in Central America and northern South America, 1961-2003. J Geophys Res Atmos 110:D23. doi:10.1029/2005JD006119

Amador JA (1998) A climatic feature of the tropical Americas: the trade wind easterly jet. Top Meteor Oceanogr 5(2):91-102

Avelino J, Cristiancho M, Georgiu S, Imbach P, Aguilar L, Bornemann G, Laderach P, Anzueto F, Hruska AJ, Morales C (2015) The coffee rust crises in Colombia and Central America (20082013): impacts, plausible causes and proposed solutions. Food Sec 7(2):3030-3321. doi:10.1007 /s12571-015-0446-9

Baca M, Laderach P, Haggar J, Schroth G, Ovalle O (2014) An integrated framework for assessing vulnerability to climate change and developing adaptation strategies for coffee growing families in Mesoamerica. PLoS ONE 9(2), e88463. doi:10.1371/journal.pone.0088463

Bouroncle C, Imbach P, Rodríguez-Sánchez B, Medellín C, Martínez-Valle A, Läderach P (2016) Mapping climate change adaptive capacity and vulnerability of smallholder agricultural livelihoods in Central America: ranking and descriptive approaches to support adaptation strategies. Clim Chang. doi:10.1007 /s10584-016-1792-0

Bunn C, Laderach P, Ovalle O, Kirschke D (2015) A bitter cup: climate change profile of global production of Arabica and Robusta coffee. Clim Chang 129(1-2):89-101

Castellanos E, Tucker C, Eakin H, Morales H, Barrera J, Díaz R (2012) Assessing the adaptation strategies of farmers facing multiple stressors: lessons from the coffee and global changes project in Mesoamerica. Environ Sci Pol 26:19-28. doi:10.1016/j.envsci.2012.07.003

Ceballos G, Ramirez J, Bellotti AC, Jarvis A, Alvarez E (2011) Adaptation of cassava to changing climates. In: Yadav SS, Redden R, Hatfield JL, Campen H-L (eds) Crop adaptation to climate change

CEPAL y CAC/SICA (2014a) Impactos potenciales del cambio climático sobre el café en Centroamérica, LC/ MEX/L.1169, México, DF

CEPAL y CAC/SICA (2014b) Impactos potenciales del cambio climático sobre los granos basicos en Centro América. LC/MEX/L.1123, México, DF

Challinor A, Wheeler T, Garforth C, Craufurd P, Kassam A (2007) Assessing the vulnerability of food crop systems in Africa to climate change. Clim Chang 83:381-399. doi:10.1007/s10584-007-9249-0

Chou SC, Lyra A, Mourão C, Dereczynski C, Pilotto I, Gomes J, Bustamante J, Tavares P, Silva A, Rodrigues D, Campos D, Chagas D, Sueiro G, Siqueira G, Marengo J (2014) Assessment of climate change over South America under RCP 4.5 and 8.5 downscaling scenarios. Am J Clim Chang 3:512-527. doi:10.4236/ajcc.2014.35043

Clark D, Clark D, Oberbauer S (2010) Annual wood production in a tropical rain forest in NE Costa Rica linked to climatic variation but not to increasing CO2. Glob Chang Biol 16:747-759. doi:10.1111/j.1365-2486.2009.02004.x

Confalonieri R, Donatelli M, Bregaglio S, Tubiello FN, Fernandes E (2012) Agroecological Zones Simulator (AZS): a component based, open-access, transparent platform for climate change — crop productivity impact assessment in Latin America. International Environmental Modelling and Software Society

Eakin H, Tucker C, Castellanos E, Díaz R, Barrera J, Morales H (2013) Adaptation in a multi-stressor environment: perceptions and responses to climatic and economic risks by coffee growers in Mesoamerica. Environ Dev Sustain 16(1):123-139. doi:10.1007/s10668-013-9466-9

Eitzinger A, Laderach P, Rizo L, Pantoja A, Gordon J (2011) Vulnerability assessment of frozen vegetable value chain to climate change. Technical report. $44 \mathrm{p}$

Eitzinger A, Laderach P, Sonder K, Schmidt A, Sain G, Beebe S, Rodriguez B, Fisher M, Hicks P, Naverate-Frias C, Nowak A (2013) Tortillas on the roaster: Central America's maize-bean systems and the changing climate. CIAT policy brief 6, CIAT, Cali 
Enquist C (2002) Predicted regional impacts of climate change on the geographical distribution and diversity of tropical forests in Costa Rica. J Biogeogr 29:519-534. doi:10.1046/j.13652699.2002.00695.x

Enquist B, Enquist C (2011) Long-term change within a neotropical forest: assessing differential functional and floristic responses to disturbance and drought. Glob Chang Biol 17:1408-1424. doi:10.1111/j.1365-2486.2010.02326.x

Fabrega J, Nakaegawa T, Pinzón R, Nakayama K, Arakawa O, SOUSEI Theme-C Modeling Group (2013) Hydroclimate projections for Panama in the late 21st century. Hydrol Res Lett 7:23-29. doi:10.3178/HRL.7.23

FAO (2015) Ecocrop database. http://ecocrop.fao.org/ecocrop/srv/en/home Curated online. Accessed Sept 2015

Feeley KJ, Silman MR (2010) Biotic attrition from tropical forests correcting for truncated temperature niches. Glob Chang Biol 16:1830-1836. doi:10.1111/j.1365-2486.2009.02085.x

Feeley K, Davies S, Perez R, Hubbell SP, Foster RB (2011) Directional changes in the species composition of a tropical forest. Ecology 92:871-882. doi:10.1890/10-0724.1

Fischlin A, Midgley GF, Price JT, Leemans R, Gopal B, Turley C, Rounsevell MDA, Dube OP, Tarazona J, Velichko AA (2007) Ecosystems, their properties, goods and services. In: Parry ML, Canziani OF, Palutikof JP, van der Linden PJ, Hanson CE (eds) Climate change 2007: impacts, adaptation and vulnerability. Contribution of working group II to the fourth assessment report of the intergovernmental panel on climate change (IPCC). Cambridge University Press, Cambridge, pp 211-272

Gourdji S, Laderach P, Valle AM, Martinez CZ, Lobell DB (2015) Historical climate trends, deforestation, and maize and bean yields in Nicaragua. Agric For Meteorol 200:270-281. doi:10.1016/j.agrformet.2014.10.002

Hannah L, Flint L, Syphard AD, Moritz MA, Buckley LB, McCullough IM (2014) Fine-grained modeling of species' response to climate change: holdouts, stepping-stones, and microrefugia. Trends Ecol Evol 29(7): 390-397. doi:10.1016/j.tree.2014.04.006

Hidalgo HG (2013) Tendencias hacia condiciones hidrológicas más secas en Centroamérica (1982-2005). VII Congreso de la Red Latinoamericana de Ciencias Ambientales, San Carlos, Costa Rica

Hidalgo H, Alfaro E (2014) Skill of CMIP5 climate models in reproducing 20th century basic climate features in Central America. Int J Climatol. doi:10.1002/joc.4216

Hidalgo H, Amador J, Alfaro E, Quesada B (2013) Hydrological climate change projections for Central America. J Hydrol 495:94-112. doi:10.1016/j.jhydrol.2013.05.004

Hidalgo H, Alfaro EJ, Quesada-Montano B (2015) Observed (1970-1999) climate variability in Central America using a high-resolution meteorological dataset with potential for climate change studies. In preparation

Imbach P, Molina L, Locatelli B, Roupsard O, Mahe G, Neilson R, Corrales L, Scholze M, Ciais P (2012) Modeling potential equilibrium states of vegetation and terrestrial water cycle of Mesoamerica under climate change scenarios. J Hydrometeorol 13:665-680. doi:10.1175/JHM-D-11-023.1

Imbach P, Locatelli B, Molina LG, Ciais P, Leadley P (2013) Climate change and plant dispersal along corridors in fragmented landscapes of Mesoamerica. Ecol Evol 3:2917-2932. doi:10.1002/ece3.672

Imbach P, Locatelli B, Zamora JC, Fung E, Calderer L, Molina L, Ciais P (2015) Part 2: climate, water and land-use changes in Central American tropical forests. In: Chiabai A (ed) Climate change impacts on tropical forests in Central America. Routledge, New York, pp 63-178

Kalnay E, Kanamitsu M, Kistler R, Collins W, Deaven D, Gandin L, Iredell M, Saha S, White G, Woollen J, Zhu Y, Leetmaa A, Reynolds R (1996) The NCEP/NCAR 40-year reanalysis project. Bull Am Meteorol Soc 77:437471. doi:10.1175/1520-0477(1996)077<0437:TNYRP>2.0.CO;2

Läderach P, Haggar J, Lau C, Eitzinger A, Ovalle O, Baca M, Jarvis A, Lundy M (2013) Mesoamerican coffee: building a climate change adaptation strategy. CIAT Policy brief n.2

Magrin G, Gay García C, Cruz Choque D, Giménez JC, Moreno AR, Nagy GJ, Nobre C, Villamizar A (2007) Latin America. Climate change 2007: impacts, adaptation and vulnerability. In: Parry ML, Canziani OF, Palutikof JP, van der Linden PJ, Hanson CE (eds) Contribution of working group II to the fourth assessment report of the intergovernmental panel on climate change. Cambridge University Press, Cambridge

Martinez A (2012) Predecir el impacto del cambio climático sobre las áreas de cultivo de cacao en Nicaragua. Final technical report. 37p

Maurer EP, Adam JC, Wood AW (2009) Climate model based consensus on the hydrologic impacts of climate change to the Rio Lempa basin of Central America. Hydrol Earth Syst Sci Discuss 13:183194. doi:10.5194/hessd-5-3099-2008

Neelin JD, Münnich M, Su H, Meyerson JE, Holloway CE (2006) Tropical drying trends in global warming models and observations. Proc Natl Acad Sci 103(16):6110-6115

Ovalle-Rivera O, Laderach P, Bunn C, Obersteiner M, Schroth G (2015) Projected shifts in Coffea arabica suitability among major global producing regions due to climate change. PLoS ONE 10(4), e0124155. doi:10.1371/journal.pone.0124155

Palmer MA, Reidy Liermann CA, Nilsson C, Florke M, Alcamo J, Sam Lake P, Bond J (2008) Climate change and the world's river basins: anticipating management options. Front Ecol Environ 6:81-89. doi:10.1890/060148 
Pazos RG (2004) Estudio del cambio climático y su efecto en la producción de granos básicos por productores de subsistencia. Proyecto de graduación de la Carrera de Desarrollo Socioeconómico y Ambiente, Zamorano, Honduras, 70p

Ramírez-Villegas J, Jarvis A, Laderach P (2013) Empirical approaches for assessing impacts of climate change on agriculture: the EcoCrop model and a case study with grain sorghum. Agric For Meteorol 170:67-78. doi:10.1016/j.agrformet.2011.09.005

Rayner S, Lach D, Ingram H (2005) Weather forecasts are for wimps: why water resource managers do not use climate forecasts. Clim Chang 69:197-227. doi:10.1007/s10584-005-3148-z

Ricketts TH, Daily GC, Ehrlich PR, Michener C (2004) Economic value of tropical forest to coffee production. PNAS 101(34):12579-12582. doi:10.1073/pnas.0405147101

Robalino J, Jimenez J, Chacón A (2015) The effect of hydro-meteorological emergencies on internal migration. World Dev 67:438-448. doi:10.1016/j.worlddev.2014.10.031

Rosenzweig C, Iglesias A, Yang XB, Epstein PR, Chivian E (2001) Climate change and extreme weather events; implications for food production, plant diseases, and pests. Glob Chang Hum Health 2(2):90-104. doi:10.1023/A:1015086831467

Santos C, Garcia S (2008) Climate change vulnerability and adaptation assessment for sugarcane and citrus. Belize Second National Communication (SNC) Project UNDP, Caribbean Community Climate Change Center

Schmidt A, Eitzinger A, Sonder K, Sain G (2012) Tortillas on the roaster: Central America's maize-bean systems and the changing climate. Full technical report

Thomas CD, Cameron A, Green RE, Bakkenes M, Beaumont LJ, Collingham YC, Williams SE (2004) Extinction risk from climate change. Nature 427(6970):145-148

Tucker CM et al (2009) Perceptions of risk and adaptation: coffee producers, market shocks, and extreme weather in Central America and Mexico. Glob Environ Chang. doi:10.1016/j.gloenvcha.2009.07.006

Tzul F, Evans F, Frutos R, Hulse J (1997) The impact of climate change on maize, R.K. beans, and rice production in Belize. Agriculture Department and National Meteorological Service, Comite Regional de Recursos Hidraulicos, Comision Centroamericano del Ambiente y Desarollo, US Country Studies Program, Proyecto Centroamericano Sobre Cambio Climatico

UNEP-ECLAC (United Nations Environmental Program-Economic and Social Commission for Latin America and the Caribbean) (2010) Vital climate change graphics for Latin America and the Caribbean: special edition for the COP16/CMP 6, Mexico. UNEP-ECLAC, Panama City

Van Zonneveld M, Jarvis A, Dvorak W et al (2009) Climate change impact predictions on Pinus patula and Pinus tecunumanii populations in Mexico and Central America. For Ecol Manag 257:15661576. doi:10.1016/j.foreco.2008.12.02

Vermeulen SJ, Aggarwal PK, Ainslie A, Angelone C, Campbell BM, Challinor AJ, Hansen JW et al (2012) Options for support to agriculture and food security under climate change. Environ Sci Pol 15(1):136-144 